\title{
Forest conservation in Russia: problems of implementation
}

\author{
Dmitry Mukhlynin ${ }^{*}$ \\ ${ }^{1}$ SIC-2 Research Institute of the Federal Penitentiary Service of Russia, 119991, 14, Zhitnyaya str., \\ Moscow, Russia
}

\begin{abstract}
In the article, the author analyses the legal and organizational problems of forest conservation in the Russian Federation. It was established that certain problems related to managerial errors, insufficient financing of the forest industry, and the imperfection of regulatory legal acts regulating these public relations impeded the effective protection of forests in Russia. Based on the analysis of statistical data and reporting materials of the Ministry of Natural Resources of the Russian Federation and other departments, it is concluded that the problems identified are multi-faceted and that a whole range of measures to protect forests is necessary. The author offers options to overcome these problems.
\end{abstract}

\section{Introduction}

The situation with forest conservation in Russia is currently under special control of the state. The events of 2019, as litmus paper, have revealed the problems of the forest industry that have been accumulating over the years, namely: large-scale forest fires, illegal logging, the presence of systemic problems associated with imperfect management, underfunding of the industry and an unbalanced distribution of powers.

The unfavorable environmental situation in the country as a whole, the updating of environmental legislation, including forest legislation, the adoption of numerous state federal and regional programs, demonstrate the great importance and determination of the state to cope with environmental problems as quickly and efficiently as possible. Among such problems there is an urgent issue of protection forests.

The study of legal and organizational problems of forest protection in the Russian Federation is reflected in the works of M.M. Mukhlynina [3], B.A. Molchanova [8], A.R. Aberkhaev, L.I. Alexandrova, B.V. Andreeva [9], M.S. Andrianov, S.A. Bogolyubov, N.D. But, D.G. Dobretsov, K.P. Ermakova [10] A.I. Nikiforova, O.N. Vedysheva, E.N. Redikultseva, R.F. Martynova [11] and others. However, issues of a comprehensive analysis of forest conservation remain understudied.

\footnotetext{
* Corresponding author: muhlynin78@ mail.ru
} 


\section{Methods}

The methodological basis of the study was the following general scientific methods: analysis and synthesis were used to study existing theoretical and methodological approaches, as well as to conduct scientific research on the protection of forests. Structural and logical methods are used to systematize the factors affecting the implementation of innovations in the legal regulation of forest protection. The factor analysis method was used to determine the influence of factors on the level of satisfaction of forest legal entities on the level of law and order in this industry.

The informational basis of the study was made up of normative legal acts, documents of state authorities and their officials, scientific works of Russian scientists on the problems of improving forest protection in modern conditions $[1,2,4,5,6.7,10]$.

\section{Results and discussion}

It should be noted that the Russian Federation is the world leader in forest area - 1184.1 million ha, or $20 \%$ of the total forest area of the world [1]. Forests in our country play a key role in various directions. They are not only "lungs of the planet" in their global environmental significance, but also export-import goods, which bring tangible budget revenues. D. Kobylkin, the head of the Ministry of Natural Resources and Ecology of the Russian Federation, notes that "the forest industry shows a statistically positive dynamics for all key indicators, but does not meet the expected results and is often criticized. In particular, from 2009 to 2019 there was more than a twofold increase in income to the country's budget for the use of forests - from 20 billion rubles up to 53 billion rubles; a significant increase in timber harvesting - from 176 million cubic meters up to 219 million cubic meters and reforestation area from 813 thousand ha to 1,127 thousand ha." [2]. Financial support from the state and the active implementation of the principle of environmental management fees contribute to the process of reforestation. According to the researcher M.M. Mukhlynina, in its content and essence, this principle of environmental management and environmental damage compensation is also connected with the solution of public legal problems of ensuring environmental well-being [3].

If we turn to the legal definition of the concept of "conservation" of forests, then the legislation, in particular, the Forest Code of the Russian Federation, contains a generalized chapter 2.4 "Conservation, protection, reforestation", which was introduced into the code structure only in 2016. The Forest Code of the Russian Federation does not contain the definition of the concept of "conservation" of the forest, revealing only the general types of protection, objects and subjects of such protection in article 50.7 of the Forest Code of the Russian Federation (hereinafter - FC RF). The concepts of "forest conservation" should also be distinguished from "forest protection", since if "conservation" is aimed at implementing protective measures against fires and pollution (radioactive and oil) (Chapter 3.2. FC RF), then "protection" involves identification of harmful organisms in forests and the prevention of their spread (Article 60.1 of the FC RF). Reforestation includes forest seed production, reproduction, and forest maintenance [4].

Thanks to the active implementation of the Ecology national project and other strategic documents by the President of the Russian Federation V.V. Putin, representatives of the authorities and the public, there is much attention paid to the problem of nature conservation and, in particular, forests in modern Russia. According to paragraph 7 of the Decree of the President of the Russian Federation dated May 7, 2018 No. 204 On National Goals and Strategic Tasks of the Development of the Russian Federation for the Period until 2024, it is necessary to ensure forest conservation, including their reproduction in all 
areas of felled and lost forest stands for the purpose of the scientific and socio-economic development of the country and improving the living standards of citizens. [5].

According to official information of the Ministry of Natural Resources and Ecology of the Russian Federation, within the framework of the federal project "Forest conservation" of the national project "Ecology", the issue of forest reproduction is now very serious. Russia is going to restore 1 million hectares of forest, 778 thousand hectares of which are on leased forest areas. The regions are assisted by forestry machinery and equipment (currently, about 150 units of machinery and more than 880 units of equipment) [6].

Violation of forest legislation is another serious problem that has to be solved, as "the volume of illegal forest management exceeds the national average in those regions of the Russian Federation where state control over the conservation of forests is weakened". Such a conclusion was made by the Council of the Federation of the Federal Assembly of the Russian Federation [7].

The legal concepts of "forest violation" among researchers differ, for example, G.N. Polyanskaya defined forest violation as "damage, destruction and theft of woody vegetation, as well as damage to land intended for natural reforestation, and all types of unauthorized use of forest land for agricultural and other purposes". Researcher B.N. Tsvetkova defines the forest violation as "an unlawful act committed by a public authority or a citizen who is not in the legal relationship of forest management and associated with an encroachment on the legal regime of forests established by a socialist state" [8].

The law and order in the field of forest protection is carried out by environmental and law enforcement agencies. The activity of environmental authorities is aimed at preserving forests, including their reproduction in all areas of deforested and lost forest plantations, as well as the implementation of many other measures in accordance with applicable law. Thanks to the active implementation of the national project Ecology and other strategic documents by the President of the Russian Federation V.V. Putin, representatives of the authorities and the public, attention to the problem of nature conservation and, in particular, forests, in modern Russia is reinforced many times.

According to official information of the Ministry of Natural Resources and Ecology of the Russian Federation, within the framework of the federal project "Forest Conservation" of the national project "Ecology", the issue of forest reproduction is now very serious. It is planned to restore 1 million hectares of forest, 778 thousand hectares of which are in leased forest areas. The problem of underfunding is currently being addressed at all levels, the regions are being helped by forestry machinery and equipment (about 150 units of machinery and more than 880 units of equipment).

The second group of bodies supporting the law and order in the field of forest protection is law enforcement agencies: their task is to carry out law enforcement activities with the aim of protecting the rights and legitimate interests of citizens, legal entities, the state and society, ensuring safety and legality. Law enforcement activity is heterogeneous, it is carried out by various bodies, which are faced with distinct, specific tasks and apply various means and methods. Let us briefly dwell on two bodies - the police and the prosecutor's office, designed to identify and stop violations of forest legislation. Police identify and investigate crimes. The powers of the prosecutor's office extend to almost all spheres of legal relations regulated by law, in particular, they exercise oversight functions, but, if necessary, take measures to restore the violated law [9]. Let us analyze the statistics of violations of forest legislation: although the volumes of illegal logging detected by state authorities of the constituent entities of the Russian Federation do not exceed 2 million cubic meters of wood, which is less than 1 percent of the volume of legal forest use, the identification of offenses is one of the serious problems. According to researchers, M.S. Andrianova, S.A Bogolyubova, N.D. But, D.G. Dobretsova, K.P. Ermakova, statistics of the use of articles of the Criminal Code of the Russian Federation, which provides for 
liability for environmental crimes, allows us to conclude that mainly crimes related to the seizure of natural resources are recorded and disclosed. In the same time, criminal environmental pollution practically does not become the subject of criminal prosecution for the vagueness of the wording of the elements of crimes in the Criminal Code of the Russian Federation [10].

Another problem of forest violations is weak state control. So "the volume of illegal forest management exceeds the national average in those regions of the Russian Federation where state control over the conservation of forests is weakened" - such a conclusion was made by the Federation Council of the Federal Assembly of the Russian Federation [7]. Researchers A.I. Nikiforov M.M. Mukhlynina, O.N. Vedysheva, E.N. Redikultseva and R.F. Martynova. They believe that the current form of state control, primarily focused on coercion and submission, has largely reached its limits, so the current situation requires a transition to preventive control, which acts as a service [11].

\section{Conclusions}

To sum up, it can be noted that at present, there are a few political and legal documents devoted to environmental protection, where the issues of rational environmental management are brought to the forefront and many issues are systematically worked out in them. Now we are reaping the benefits of civil law relations introduced in the Forest Code of the Russian Federation in the field of turnover of forest areas, which have actually relieved tenants of their duty to take care of forests, ensure fire safety. The forests that have not been leased out have completely lost real protection from negative factors. The weakening of the control function also contributed to an increase in the number of forest violations. According to the researchers, a return to the stable functioning of the management system and overcoming the legal nihilism of forest users will require years and considerable efforts on the part of the control and supervisory authorities.

The state has taken forests under its tight control. Note that more than one ministry is responsible for the law and order in this industry; many bodies are involved in the work, including law enforcement agencies. Forest protection is a very complex set of measures. The effectiveness of the mechanism of environmental and legal regulation can be promoted only by overcoming defects in legal regulation.

\section{References}

1. Report of the Chairman of the Committee of the State Duma of the Russian Federation on Natural Resources, Property and Land Relations Nikolaev N.P. Natural Resources: Efficiency and Control (2017) URL: http: // komitet31.test.km.duma.gov.ru/upload/site49/document_news/000/264/228/doklad.pdf. (accessed date 08/05/2018).

2. Website of the Ministry of Natural Resources of Russia [Electronic resource]. URL:http://www.mnr.gov.ru/press/news/glava_minprirody_rossii_predstavil_osnovy_ strategii_razvitiya_lesnoy_otrasli_na_printsipakh_sinkhron/ (accessed 08.03.2020).

3. M.M. Mukhlynina, Ensuring the implementation of the principle of environmental management paid and environmental damage in the interpretative acts of the Constitutional Court of the Russian Federation, (Nizhny Novgorod Academy of the Ministry of Internal Affairs of the Russian Federation, Nizhny Novgorod, 2020)

4. Forest Code of the Russian Federation dated December 4, 2006 No. 200-FZ (as amended on December 27, 2018) 
5. Decree of the President of the Russian Federation of May 7, 2018 No. 204 On national goals and strategic objectives of the development of the Russian Federation for the period until 2024

6. Website of the Ministry of Natural Resources of Russia [Electronic resource]. URL: http://www.mnr.gov.ru/press/news/federalnyy_proekt_sokhranenie_lesov_vosstanovle no_245_tysyach_ga_lesnykh_nasazhdeniy/(accessed 10.03.2020).

7. Decree of the Council of the Federation of the Federal Assembly of the Russian Federation dated January 30, 2019 No. 17-SF On Strengthening Control over the Turnover of Wood and Counteracting its Illegal Logging [

8. B. Molchanov, Legal protection of Russian forests of the twentieth and early twentyfirst centuries: Textbook, (Vladimir State University, Vladimir, 2005)

9. A.R. Aberkhaev, L.I. Aleksandrova, B.V. Andreev, The prosecutor's handbook (Moscow, 2019)

10. M.S. Andrianov, S.A. Bogolyubov, N.D. But, D.G. Dobretsov, K.P. Ermakova and others, Legality: theory and practice: monograph (Institute of Legislation and Comparative Law under the Government of the Russian Federation, Academy of the Prosecutor General of the Russian Federation: Law Firm Contract, Moscow, 2017) URL: https://base.garant.ru/ (access date 05/15/2019).

11. A.I. Nikiforov, M.M. Mukhlynina, O.N. Vedysheva, E.N. Redikultceva, R.F. Martynova, Technologies and main modern economic and legal aspects of the formation of state control systems (supervision) over the use of natural resources, International Journal of Engineering and Advanced Technology (IJEAT), 8, 2255 (2019) 